\title{
Classification of planktonic stages of extant brachiopods
}

\author{
V.V. Malakhov' ${ }^{1}$, T.V. Kuzmina ${ }^{1}$, A.A. Madison ${ }^{2}$ \\ ${ }^{1}$ Lomonosov Moscow State University, Vorobjevi gory 1? 12, Moscow, 119991 Russian Federation. \\ E-mail:vmalakhov@inbox.ru,kuzmina-t@yandex.ru \\ ${ }^{2}$ Borisyak Paleontological Institute, Russian Academy of Sciences, Profsoyuznaya ul. 123, Moscow, \\ 117997 Russian Federation. E-mail: sunnyannmad@yahoo.com
}

ABSTRACT: Brachiopods are characterized by a pelago-benthic life cycle and strongly differ in their planktonic stages. However, the planktonic stages in brachiopod ontogeny still do not have special names. Here we propose names for all planktonic stages of extant brachiopods. The chaetotrocha is a larva consisting of a round anterior lobe with a ciliary band and a body with three pairs of larval setae bundles. Lecithotrophic chaetotrocha is a larva of extant Craniiformea. The cephalula is a larva divided into the anterior lobe bearing the apical ciliary tuft and a marginal ciliary band, a mantle lobe with larval setal bundles, and a pedicle lobe. Lecithotrophic cephalula is the only larval stage of recent Rhynchonelliformea. The development of Discinidae includes three planktonic stages succeeding each other. The first is the cephalula. Second developmental stage of Discinidae is the chaetolopha with a rudimentary lophophore and larval spinose setae. The third stage of discinid development is the tegulolopha with a lophophore and a shell. The only planktonic stage of extant Lingulidae is the tegulolopha. Larvalization and embryonization are the main trends in the evolution of larval development of brachiopods.

How to site this article: Malakhov V.V., Kuzmina T.V., Madison A.A. 2021. Classification of planktonic stages of extant brachiopods // Invert. Zool. Vol.18. No.2. P.95-104. doi: 10.15298/invertzool.18.2.04

KEY WORDS: Brachiopoda, larval development, chaetotrocha, cephalula, chaetolopha, tegulolopha, larvalization, embryonization.

\section{Классификация планктонных стадий современных брахиопод}

\author{
В.В. Малахов" ${ }^{1}$ Т.В. Кузьмина ${ }^{1}$, А.А. Мадисон ${ }^{2}$
}

\footnotetext{
${ }^{1}$ Кафедра зоологии беспозвоночных, Биологический факультет МГУ имени М.В. Ломоносова, Ленинские горы 1-12, 119991 Москва, Россия. E-mail: vmalakhov@inbox.ru, kuzminat@yandex.ru

${ }^{2}$ Палеонтологический институт им. АА. Борисяка, ул. Профсоюзная, 123, Москва 117997, Россия. E-mail: sunnyannmad@yahoo.com
}

РЕЗЮМЕ: Брахиоподы имеют пелаго-бентический жизненный цикл, и их планктонные стадии существенно различаются. Планктонные стадии в онтогенезе брахиопод до сих пор не имеют специальных названий. Мы предлагаем названия для всех планктонных стадий современных брахиопод. Хетотроха - это личинка, состоящая из округлой передней лопасти, окруженной ресничным шнуром, и туловищного отдела с тремя парами пучков личиночных щетинок. Хетотроха является личинкой 
современных Craniiformea. Цефалула - это личинка, подразделенная на три лопасти: переднюю, несущую апикальный пучок ресничек и ресничный шнур, мантийную, несущую пучки личиночных щетинок, и педальную. Лецитотрофная цефалула является единственной личиночной стадией современных Rhynchonelliformea. Развитие Discinidae включает три планктонные стадии, сменяющие друг друга. Первая — это цефалула. Вторая стадия Discinidae - это хетолофа, имеющая зачаточный лофофор и личиночные зазубренные щетинки. Третья стадия Discinidae - это тегулолофа, имеющая лофофор и раковину. У современных Lingulidae из яйца вылупляется тегулолофа. Планктотрофная тегулолофа - единственная планктонная стадия современных Lingulidae. В эволюции личиночного развития брахиопод имеется два тренда - ларвализация и эмбрионизация.

Как цитировать эту статью: Malakhov V.V., Kuzmina T.V., Madison A.A. 2021. Classification of planktonic stages of extant brachiopods // Invert. Zool. Vol.18. No.2. P.95-104. doi: 10.15298/invertzool.18.2.04

КЛЮЧЕВЫЕ СЛОВА: Брахиоподы, личиночное развитие, хетотроха, цефалула, хетолофа, тегулолофа, ларвализация, эмбрионизация.

\section{Introduction}

The phylum Brachiopoda is subdivided into three subphyla, Linguliformea, Craniiformea, and Rhynchonelliformea (Williams et al., 1996). These subphyla represent three distinct evolutionary trends that probably diverged in the Early Cambrian (Harper et al., 2017). All recent brachiopods have a pelago-benthic life cycle. The planktonic stages of the brachiopod life cycle considerably differ in their morphology in all three subphyla. Recent Rhynchonelliformea have shell-less lecithotrophic larvae with a ciliary band and two pairs of setal bundles (Kovalevsky, 1874, 1883; Conklin, 1902; Percival, 1944, 1960; Malakhov, 1976, 1983; Chuang, 1996; Freeman, 1993, 2003; Grobe, Lüter, 1999; Pennington et al., 1999; Zakrzewski et al., 2012; Kuzmina et al., 2019, etc.). The lecithotrophic larvae of recent Craniiformea also lack the shell but have a ciliary band and three pairs of setal bundles (Nielsen, 1991; Altenburger, Wanninger, 2010; Altenburger et al., 2013). Extant Linguliformea comprise only two families, Discinidae and Lingulidae. The planktonic period of the discinid life cycle includes several stages, the first one has a ciliary band and setae, the next stage possesses a rudimentary lophophore and setae, and the third stage develops a lophophore and a shell (Chuang, 1977; Freeman, 1999;
Lüter, 2001). The only lingulid planktonic stage is planktotrophic and possesses shell and lophophore (Yatsu, 1902; Paine, 1963; Freeman, 1995; Collin et al., 2019). Several attempts have been made to reconstruct the planktonic stages of fossil brachiopods (Popov et al., 2007; Freeman, Lundelius, 2005; Zhang et al., 2018; Madison, Kuzmina, 2019a, b; Madison et al., 2021).

The terminology for planktonic developmental stages in other groups of animals is wellestablished: trochophore, metatrochophore and nectochaete for polychaetes, veliger for mollusks, actinotrocha for phoronids, etc. The echinoderms are characterized by a wide diversity of larval types and the terminology within Echinodermata is elaborated for each class separately (bipinnaria for asteroids, auricularia for holothurians, etc.). The planktonic developmental stages of different groups of brachiopods are also highly variable and differ in morphology from other invertebrate larvae but still don't have generally accepted names. Beecher (1892) gave the name 'cephalula' to a three-lobed rhynchonelliform larva. This name had been mentioned several times in old publications on brachiopods (Schuchert, 1897; Beecher, 1902; Jackson, 1913; Joseph, 1937) but never in the later reviews on brachiopod morphology and embryology (Hyman, 1959; Ivanova-Kazas, 1977; 
James et al., 1992; Williams et al., 1997; Santagata, 2015). However, 'cephalula' was included in some modern zoological dictionaries (Lawrence, 2005; Maggenti, 2005) and defined as 'a free-living embryonic stage in some brachiopods' without a reference to rhynchonelliforms (Lawrence, 2005: 109). Starobogatov (1979) proposed the term 'malleula' for the metamorphosing larva of phoronids. He suggested that the shelled planktonic stage of lingulids could also be considered as a 'malleula' (Starobogatov, 1979).

As the terminology for the brachiopod planktonic developmental stages still is not elaborated, here we introduce a new classification of these stages for all groups of recent brachiopods.

\section{Types of brachiopod planktonic stages}

The chaetotrocha (from the Greek khaitç (long hair) and trokhos (wheel) meaning a ciliary band) is a larva consisting of a round anterior lobe with a ciliary band and a body with three pairs of larval setal bundles (Fig. 1A-B). The chaetotrocha is a larva of recent craniid brachiopods (Nielsen, 1991; Altenburger, Wanninger, 2010; Altenburger et al., 2013). Although the surface of the anterior lobe of craniid larva is covered with cilia entirely, a wide densely ciliated band delimiting the anterior lobe posteriorly is well distinguishable (Nielsen, 1991). The body of the craniid chaetotrocha bears cilia on the ventral and lateral sides and three pairs of bundles of spinose setae arranged dorsolaterally along the anteroposterior body axis (Fig. 1A) (Nielsen, 1991). Each pair of setal bundles protrudes from the setal sack formed by invagination of larval epidermis. The dorsal side bears an oval area of thickened epidermis covered with cuticle (Fig. 1A).

According to Nielsen (1991), at settlement the craniid chaetotrocha folds on the ventral side and its anteroposterior axis curves. The dorsal valve forms at the site of the cuticular area. The attachment site corresponds to the area of the dorsal side of the swimming larva behind the dorsal valve precursor. The third pair of setae is shed at metamorphosis. The ventral valve is secreted later by the epithelium of the attachment area. These data served as basis for the theory of folding (Nielsen, 1991). The folding theory has been supported by a number of authors (Malakhov, 1995; Cohen et al., 2003; Lüter, 2007; Malakhov, Kuzmina, 2006; Kuzmina et al., 2019). Other authors argue against the folding theory (Altenburger et al., 2013, 2017). In any case, the craniid larva distinctly differs from the larvae of other brachiopods and deserves a special name.

As it was mentioned above, the name cephalula was first introduced for the larvae of rhynchonelliform brachiopods (Beecher, 1892). Though it is now rarely used, it is not a reason for not using this name. The cephalula consists of three lobes: anterior, mantle, and pedicle (Fig. 1C) (Kovalevsky, 1874, 1883; Conklin, 1902; Percival, 1944, 1960; Malakhov, 1976, 1983; Chuang, 1996; Freeman, 1993, 2003; Grobe, Lüter, 1999; Pennington et al., 1999; Zakrzewski et al., 2012; Santagata, 2015; Kuzmina et al., 2019). The anterior lobe bears an apical organ. A wide, densely ciliated band delimits the anterior lobe posteriorly. The ventral side of the mantle lobe bears another ciliary band, the neurotroch. Initially the mantle lobe of the early larva develops obliquely to the anteroposterior body axis (Kuzmina et al., 2019). Then the mantle lobe increases in size by growth of its dorsal region. The cephalula of rhynchonelliforms preserves only two pairs of spinose larval setal bundles that correspond to the number of setal bundles of the newly settled craniide larva (see Nielsen, 1991). The inner mantle epidermis of competent larva secretes the proteinaceous periostracum (Malakhov, 1983; Stricker, Reed, 1985a, b). Altenburger et al. (2013) pointed out that the Novocrania larva resembles an early stage of the rhynchonelliform larva, at which its mantle is not separated from the pedicle lobe. However, the rhynchonelliform cephalula strongly differs from the craniid chaetotrocha in the presence of two pairs of setal bundles, a clearly defined apical ciliary tuft, and the development 


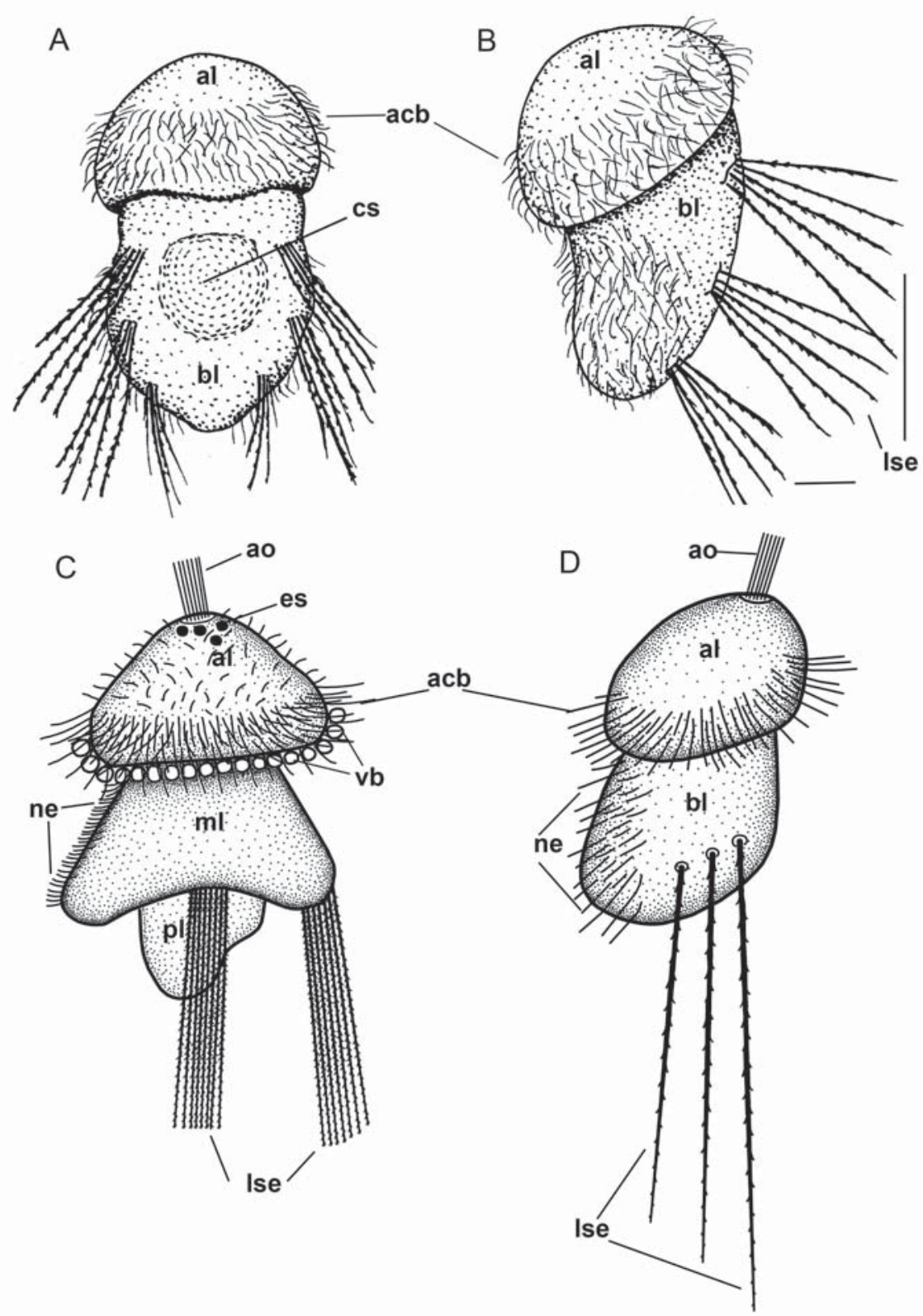

Fig. 1. Chaetotrocha and cephalula. A, B - chaetotrocha of craniids (after Nielsen, 1991): A - dorsal view; B lateral view; C - lateral view of the rhynchonelliform cephalula (after Stricker, Reed, 1985; Pennington et al., 1999; Kuzmina et al., 2019); D — lateral view of discinid cephalula (after Freeman, 1999; Lüter, 2001, 2007). Abbreviations: acb — anterior lobe ciliary band; ao — apical organ; al — anterior lobe; bl — body lobe; cs — cuticular shield, precursor of dorsal periostracum; es - eyespots; lse — larval setae; $\mathrm{ml}$ — mantle lobe; ne — neurotroch; $\mathrm{vb}$ - vesicle bodies. Рис. 1. Хетотроха и цефалула. А, В — хетотроха краниид (по Nielsen, 1991): А — вид с дорсальной стороны; В - вид сбоку; С - цефалула ринхонеллиформных брахиопод, вид сбоку (по Stricker, Reed, 1985; Pennington et al., 1999; Kuzmina et al., 2019); D - цефалула дисцинид, вид сбоку (по Freeman, 1999; Lüter, 2001, 2007).

Обозначения: acb — ресничный шнур на передней лопасти; ао — апикальный орган; al — передняя лопасть; bl — туловищный отдел; cs — кутикулярное поле; es — глазные пятна; lse — личиночные щетинки; ml — мантийная лопасть; ne - невротрох; vb - везикулярные тельца. 
of mantle folds. Thus, to avoid confusion, these larval types should be separated.

The name cephalula is also applied to a newly hatched discinid larva. In discinids, the cephalula is the first planktonic stage, which leaves the egg envelope and starts living in the water column. The discinid cephalula consists of the anterior and body lobes (= mantle lobe by Freeman, 1999) (Fig. 1D). The anterior lobe bears an apical tuft of cilia (Freeman, 1999). The early larva is uniformly covered with cilia; while later stages bear a wide ciliary band at the anterior lobe and a ciliary band corresponding to the neurotroch along the ventral side (Freeman, 1999; Lüter, 2001). The two-lobed discinid larva has three long spinose larval setae on each side of its body (Chuang, 1977). According to ultrastructural data, the larval setal pouches of rhynchonelliforms, craniiforms, and discinids are similarly structured (Lüter, 2000, 2001, 2007). Since the structure of the discinid larva is similar to that of rhynchonelliforms (q.v. Freeman, 2003; Santagata, 2015; Kuzmina et al., 2019), it can be considered as cephalula. The newly hatched discinid cephalula does not have a mouth and anus (see Luter, 2005), but later it develops a mouth and anus and becomes planktotrophic (Freeman, 1999).

The chaetolopha (from the Greek khaitç (long hair) meaning a seta and lophos (crest) meaning a lophophore) is the next planktonic stage of discinids. The chaetolopha is a peculiar morphological type of brachiopod planktonic stages that has a lophophore and spinose larval setae but lacks the shell (Fig. 2A). The discinids are the only group of extant brachiopods with a chaetolopha in their life cycle (Table 1). The first three tentacles (one median and two lateral) form the chaetolopha lophophore (Freeman, 1999). The discinid chaetolopha has a mouth, anus and functioning intestine; thus, it is a true planktotrophic stage (Chuang, 1977).

The tegulolopha (from the Latin tegere (to cover) meaning a shell and the Greek lophos (crest) meaning a lophophore) is a planktonic stage having both a lophophore and a shell. The discinid tegulolopha replaces the chaetolopha in the ontogeny (Fig. 2B). In extant lingulids, the tegulolopha hatches from the egg envelopes, and therefore it is the only planktonic stage in their life cycle (Fig. 2C-D) (Yatsu, 1902; Chuang, 1977; Freeman, 1999; Kuzmina et al., 2019). Starobogatov (1979) suggested the name 'malleula' for the phoronid larva at metamorphosis with a protruding metasomal outgrowth. According to Starobogatov (1979), the lingulid pedicle is a homologue of the metasomal outgrowth of phoronids and that is why he supposed the shelled lingulid larva to be 'malleula' (Starobogatov, 1979). The homology between the lingulid pedicle and the phoronid metasomal outgrowth has not been proven; thus the term 'malleula' cannot be applied to the lingulid planktonic stage.

Both in discinids and lingulids, the shell of the full-grown tegulolopha is subdivided into the protegulum and brephic shell (Fig. 2B, D). In extant discinids, the protegulum forms at the stage of 3 pairs of tentacles (Fig. 2B) The discinid protegulum is circular, with a diameter of about $70 \mu \mathrm{m}$ (Chuang, 1977). Tiny silicon chips covering the periostracum of the discinid brephic shell do not preserve in adults (Williams et al., 2001; Lüter, 2004). The lingulid tegulolopha hatches from the egg already having a semicircular protegulum (Fig. 2C). The straight posterior margin of the protegulum is about 120-280 $\mu \mathrm{m}$ long (Yatsu, 1902; Paine, 1963; Freeman, 1995; Collins et al., 2019). The protegulum of discinids and lingulids is smooth while their brephic shell bears clearly visible growth lines (Madison et al., 2021).

In discinids, the early tegulolopha preserves spinose larval setae. Curved and flexible setae appear at the stage of four pairs of lophophore tentacles while the spinose setae are still present (Fig. 2B). In full-grown tegulolopha, the spinose setae are shed and the number of curved and flexible setae increases. After settling, the curved setae are shed too, but the flexible setae may persist in adults (Chuang, 1977). The lingulids lack spinose larval setae. Adult setae develop along the mantle margins of the lingulid planktonic tegulolopha at the stage of seven pairs of tentacles (Yatsu, 1902). The lingulid tegulolopha settles at the stage of 10-15 pairs of 


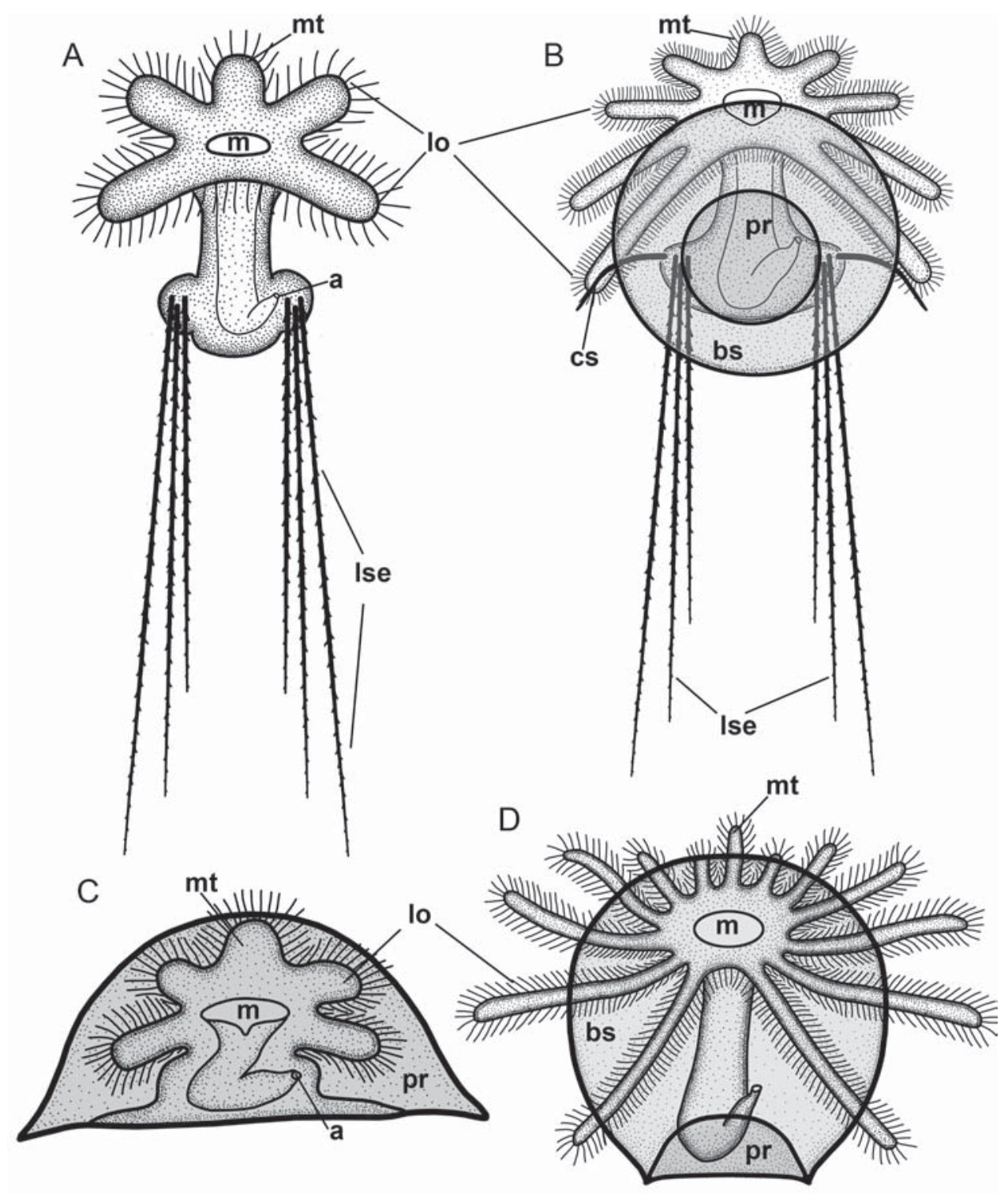

Fig. 2. Chaetolopha and tegulolopha (dorsal view). A — discinid chaetolopha (after Chuang, 1977; Freeman, 1999); B - discinid tegulolopha at the stage of four pairs of tentacles, three pairs of larval spinous setae are still retained, first pair of curved setae is developed (after Chuang, 1968, 1977; Hammond, 1980; Collin et al., 2019); C — lingulid tegulolopha immediately after hatching (after Yatsu, 1902: Freeman, 1995); D full-grown lingulid tegulolopha (after Yatsu, 1902; Hammond, 1982; Collin et al., 2019).

Abbreviations: a — anus; bs — brefic shell; cs — curved seta; lse — larval setae; lo — lophophore; $\mathrm{m}$ — mouth; $\mathrm{mt}$ median tentacle; $\mathrm{pr}$ - protegulum.

Рис. 2. Хетолофа и тегулолофа (вид с дорсальной стороны). А - хетолофа дисцинид (по Chuang, 1977; Freeman, 1999); В - тегулолофа дисцинид на стадии 4 пар щупалец, имеются три пары личиночных щетинок, появилась первая пара изогнутых щетинок (по Chuang, 1968, 1977; Hammond, 1980; Collin et al., 2019); С — тегулолофа лингулид сразу после вылупления (по Yatsu, 1902: Freeman, 1995); D — тегулолофа лингулид (по Yatsu, 1902; Hammond, 1982; Collin et al., 2019).

Обозначения: a - aнyc; bs - брефическая раковина; cs - изогнутая щетинка; lse - личиночные щетинки; lo лофофор; $\mathrm{m}$ - рот; $\mathrm{mt}$ - среднее щупальце; $\mathrm{pr}$ - протегулюм. 
Table 1. Types of planktonic stages in different groups of recent brachiopods. Таблица 1. Типы планктонных стадий в разных группах современных брахиопод.

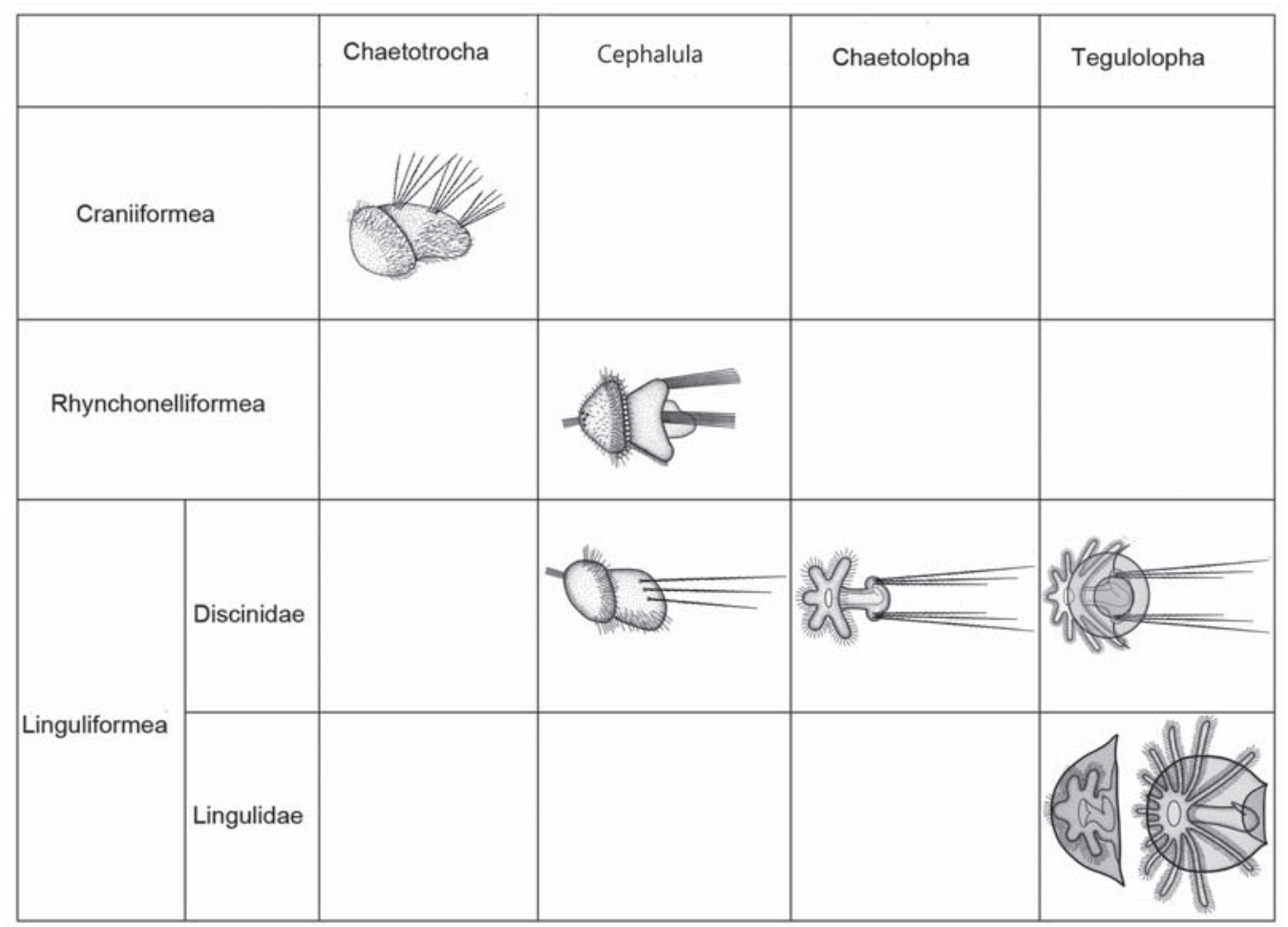

tentacles (Yatsu, 1902; Ashworth, 1915). Discinisca laevis (Sowerby, 1822) was found settled at the stage of six pairs of tentacles (Williams, Rowell, 1965).

The affiliation of different types of planktonic stages to higher brachiopod taxa is shown in Table 1.

\section{Evolution of larval development in brachiopods}

In a previous study (Kuzmina et al., 2019), we assumed that the brachiopod ancestors had a typical pelago-benthic life cycle with external fertilization, a ciliary blastula, a gastrula, and a planktotrophic larva with ciliary bands. The life cycle of extant Craniiformea closely resembles this prototype. The only difference is that the larva of extant craniids is lecithotrophic. The chaetotrocha of craniids may be considered as the plesiomorphic variety of planktonic stages of recent brachiopods. The craniid chaetotrocha resembles planktonic larvae of other invertebrates, for instance, the nektochaeta of some polychaetes.

Kuzmina et al. (2019) speculated the rhynchonelliform larva corresponds to the folding metamorphosing stage of craniids ascended into the water column. Since some authors (Altenburger et al., 2013, 2017) adduce serious arguments against the theory of folding, this interpretation remains hypothetical.

The discinid chaetolopha demonstrates evidence of heterochrony. The presence of spinose larval setae is a larval feature while the development of the lophophore is typical for benthic juveniles. The discinid tegulolopha loses larval characteristics with the shedding of spinose setae. The full-grown tegulolopha is in fact a brachiopod juvenile adapted to floating in the water column. Thus, the tegulolopha is an example of larvalization. The larvalization is an 
evolutionary trend when benthic juveniles transform to planktonic larvae and acquire adaptations to pelagic conditions. Larvalization is probably the main evolutionary way to prolongate the planktonic phase of bilaterian life cycle (see Malakhov et al., 2019).

The lingulids show another trend in the evolution of brachiopod life cycles: embryonization. The term embryonization was actively used by Russian authors, for example, Schmalhausen (1942), Sachwatkin (1956), IvanovaKazas $(1975,1995)$ but is poorly known in other countries. Embryonization means that the ontogenetic stages "that originally occurred at the postembryonic stages are now included into the embryonic development" (Ivanova-Kazas, 1975: 72). All developmental stages of recent lingulids preceding the tegulolopha occur within the egg envelope and are actually stages of embryonic development. In recent lingulids, the shelled juvenile hatches and is adapted to swimming in the water column; it serves distribution as is the case for various ciliated larvae of other invertebrates.

Acknowledgements. The authors are grateful to anonymous reviewers for their valuable comments and suggestions. This study was supported by fund from the Russian Foundation for Basic Research No. 19-04-00449: the description of morphology of the planktonic stages. The literature analysis was supported by a fund the Russian Science Foundation (No. 1814-00082). The research was carried out as part of the Scientific Project of the State Order of the Government of Russian Federation to Lomonosov Moscow State University no. 121032300121-0.

\section{References}

Altenburger A., Wanninger A., Holmer L.E. 2013. Metamorphosis in Craniiformea revisited: Novocrania anomala shows delayed development of the ventral valve // Zoomorphology. Vol.132. P.379-387.

Altenburger A., Wanninger A. 2010. Neuromuscular development in Novocrania anomala: evidence for the presence of serotonin and a spiralian-like apical organ in lecithotrophic brachiopod larvae // Evol. Dev. Vol.12. No.1. P.16-24.
Ashworth J.H. 1915. On larvae of Lingula and Pelagodiscus (Discinisca) // Trans. R. Soc. Edinburgh. Vol.51. P.45-69.

Beecher C.E. 1892. Development of the Brachiopoda, part II // Amer. J. Sci. Ser.3. Vol. 44. P.133-155.

Beecher C. 1902. Recent papers on the embryology, structure and habits of living Brachiopoda // Science. New Ser. Vol. 16. No. 414. P.901-902.

Chuang S.H. 1977. Larval development in Discinisca (inarticulate brachiopod) // Am. Zool. Vol.17. P.3953.

Chuang S.H. 1996. The embryonic, larval, and early postlarval development of the terebratellid brachiopod Calloria inconspicua (Sowerby) // J. R. Soc. New Zealand. Vol.26. No.1. P.119-137.

Cohen B.L., Holmer L.E., Lüter C. 2003. The brachiopod fold: a neglected body plan hypothesis // Palaeontology. Vol. 46. P.59-65.

Collin R., Venera-Pontón D.E., Driskell A.C., Macdonald K.S., Boyle M.J. 2019. Planktotrophic brachiopod larvae from the Pacific and Caribbean of Panama // Diversity. Vol.11:2.

Conklin E.G. 1902. The embryology of a brachiopod, Terebratulina septentrionalis Couthouy // Proc. Am. Philos. Soc. Vol.41. P.41-76.

Freeman G. 1993. Regional specification during embryogenesisin the articulate brachiopod Terebratalia // Dev. Biol. Vol.160. No.1. P.196-213.

Freeman G. 1995. Regional specification during embryogenesis in the inarticulate brachiopod Glottidia // Dev. Biol. Vol.172. P.15-36.

Freeman G. 1999. Regional specification during embryogenesis in the inarticulate brachiopod Discinisca // Dev. Biol. Vol.209. P.321-339.

Freeman G. 2003. Regional specification during embryogenesis in Rhynchonelliform brachiopods // Dev. Biol. Vol.261. P.268-287.

Freeman G., Lundelius J.W. 2005. The transition from planktotrophy to lecithotrophy in larvae of Lower Palaeozoic Rhynchonelliform brachiopods // Lethaia. Vol.38. P.219-254.

Grobe, P., Lüter C. 1999. Reproductive cycles and larval morphology of three recent species of Argyrotheca (Terebratellacea: Brachiopoda) from Mediterranean submarine caves // Mar. Biol. Vol.134. P.595-600.

Harper D.A.T., Popov L.E., Holmer L.E. 2017. Brachiopods: origin and early history // Paleontology. Vol.60. No.5. P.609-631.

Hyman L.H. 1959. The Invertebrates. Vol.5. Smaller Coelomate Groups. New York: McGraw-Hill Book Company. 783 p.

Ivanova-Kazas O.M. 1975. [Comparative embryology of invertebrate animals: protozoans and lower metazoans]. Novosibirsk: Nauka. 372 p. [In Russian]

Ivanova-Kazas O.M. 1977. [Comparative embryology of invertebrate animals. Trochozoans, lophophorates, chaetognaths, pogonophores]. Moscow: Nauka. 312 p. [In Russian]

Ivanova-Kazas O. M. 1995. [Evolutionary Embryology of Animals). St. Petersburg: Nauka. 565 p. [In Russian] 
Jackson R.T. 1913. Alpheus Hyatt and his principles of research // Am. Natur. Vol.47. No.556. P.195-205.

James M.A., Ansell A.D., Collins M.J., Curry G.B., Peck L.S., Rhodes M.C. 1992. Biology of living brachiopods // Advances in marine biology. Vol.28. P.175387.

Joseph J.K.S.St. 1937. The pentameracea of the Oslo region being a description of the Kiær collection of pentamerids // Norsk Geologisk Tidsskift. Vol.17. Issue 4. P.225-336.

Kovalevsky A.O. 1874. [On the development of the Brachiopoda] // Izvestia Obshchestva Liubiteley Estestvoznaniya, Anthropologii i Etnographii. Vol.14. P.1-40 [in Russian].

Kovalevsky A.O. 1883. Observations sur le developpement des brachiopods (Analysis by Oehlert and Deniker) // Arch. Zool. Exp. Gen. Sér. 2. P.57-76.

Kuzmina T.V., Malakhov V.V., Temereva E.N. 2019. Larval development of the brachiopod Coptothyris grayi (Davidson, 1852) (Terebratulida: Rhynchonelliformea) and the evolution of brachiopod life cycles // Invert. Zool. Vol.16. No.1. P.27-40.

Lawrence E. 2005. Henderson's dictionary of Biology. Harlow, England. 13th Edition. 748 p.

Lüter C. 2000. The origin of the coelom in Brachiopoda and its phylogenetic significance // Zoomorphology. Vol.120. P 15-28.

Lüter C. 2001. Brachiopod larval setae - a key to the phylum's ancestral life cycle? // H. Brunton, L.R.M. Cocks, S.L. Long (eds.). Brachiopods Past and Present. Proceedings of the Millennium Brachiopod Congress, 2000. The Systematics Association. Special Volume Series 63. London: Taylor and Francis. P.46-55.

Lüter C. 2004. How brachiopods get covered with nanometric silicon chips // Proc. R. Soc. Lond. B (Suppl.) Biol. Lett. Vol.271. P.S465-S467.

Lüter C. 2007. Anatomy // P.A. Selden (ed.). Treatise on Invertebrate Paleontology, Part H, Brachiopoda (Revised). Boulder (Co) - Lawrence (Ks): Geol. Soc. Am. - Univ. Kansas Press. Vol.6. P.423-440.

Madison A.A., Kuzmina T.V. 2019a. The tube-like structures on the juvenile shells of earliest strophomenides and billingsellides as evidence of their life cycles // Lethaia. Vol.53. No.1. P.91-105.

Madison A.A., Kuzmina T.V. 2019b. Early paleozoic brachiopod larva: True larva, not a juvenile // Invert. Zool. Vol.16. No.1. P.41-47.

Madison A.A., Kuzmina T.V., Temereva E.N. 2021. Analysis of the juvenile shell of Lingula anatina (Brachiopoda: Linguliformea) provides insight into the evolution of life cycles of fossil brachiopods // Paleobiology. Vol.47. P.134-148.

Maggenti A.R. 2005. Online Dictionary of Invertebrate Zoology. digitalcommons.unl.edu. 963 p.

Malakhov V.V. 1976. [Certain stages of embryogenesis in Cnismatocentrum sakhaliensis parvum (Brachiopo$\mathrm{da}$, Testicardines) and the problem of evolution of the way of origin of coelomic mesoderm] // Zoologicheskii Zhurnal. Vol.55. No.1. P.66-75 [in Russian, with English summary].
Malakhov V.V. 1983. [Anatomy of the Larvae of the Articulate Brachiopod Cnismatocentrum sakhaliensis parvum] // Trudy Zoologicheskii Instituta AN SSSR. Vol.109. P.147-155 [in Russian].

Malakhov V.V. 1995. [The problem of basic plan of brachiopod structure and their position in the system of the animal kingdom] // Sovremennoe sostoyanie i osnovnye napravleniya izucheniya brakhiopod. Moscow. P.51-82 [in Russian].

Malakhov V.V., Bogomolova E.V., Kuzmina T.V., Temereva E.N. 2019. Evolution of metazoan life cycles and the origin of pelagic larvae // Russ. J. Dev. Biol. Vol.50. No.6. P.303-316.

Nielsen C. 1991. The development of the brachiopod Crania (Neocrania) anomala (O.F. Müller) and its phylogenetic significance // Acta Zool. Vol.72. P.7-28.

Paine R.T. 1963. Ecology of the Brachiopod Glottidia pyramidata // Ecol. Monogr. Vol.33. P.187-213.

Pennington J.T., Tamburri M.N, Barry J.P. 1999. Development, temperature tolerance, and settlement preference of embryos and larvae of the articulate brachiopod Laqueus californianus // Biol. Bull. Vol.196. P.245-256.

Percival E. 1944. A contribution to the life-history of the brachiopod Terebratella inconspicua Sowerby // Trans. R. Soc. New Zealand. Vol.74. P.1-23.

Percival E. 1960. A contribution to the life-history of the brachiopod Tegulorhynchia nigricans // Quat. J. microsc. Sci. Vol.101. P.439-457.

Popov L.E., Egerquist E., Holmer L.E. 2007. Earliest ontogeny of Middle Ordovician rhynchonelliform brachiopods (Clitambonitoidea and Polytoechioidea): implications for brachiopod phylogeny // Lethaia. Vol.40. P.85-96.

Sachwatkin A.A. 1956. Vergleichende Embryologie der niederen Wirbellosen. Ursprung und Gestaltungswege der individuellen Entwicklung der Vielzeller. Berlin: Deutscher Verlag der Wissensehaften. $401 \mathrm{~S}$.

Santagata S. 2015. Brachiopoda // Wanninger A. (ed.). Evolutionary Developmental Biology of Invertebrates. Wien: Springer. Vol. 2. Lophotrochozoa (Spiralia). P.263-277.

Schmalhausen I.I. 1942. [Organism as a whole in individual and historical development]. Moscow-Leningrad: Acad. Sci. USSR. 211 p. [In Russian]

Schuchert C. 1897. A synopsis of American fossil Brachiopoda including bibliography and synonymy // Bull. U.S. Geol. Survey. No.87. P.1-464.

Starobogatov Ya.I. 1979. [Evolution of pelagic larvae of Protostomia and problem of main body components] // Zool. Zhurn. Vol.58. P.149-160 [in Russian with English summary].

Stricker S.A., Reed C.G. 1985a. The ontogeny of shell secretion in Terebratalia transversa (Brachiopoda, Articulata) I. Development of the mantle // J. Morphol. Vol.183. P.233-250.

Stricker S.A., Reed C.G. 1985b. The ontogeny of shell secrtion in Terebratalia transversa (brachiopoda, articulata) II. Formation of the protegulum and metamorphic shell // J. Morphol. Vol.183. P.251-271. 
Williams A., Carlson S.J., Brunton C.H.C., Holmer L.E., Popov L. 1996. A supra-ordinal classification of the Brachiopoda // Philos. Trans. R. Soc. B. Vol.351. No.1344. P.1171-1193.

Williams A., James M.A., Emig C.C., Mackay S., Rhodes M.C. 1997. Anatomy // Kaesler R.L. (ed.). Treatise on invertebrate paleontology. Boulder, Colorado, and Lawrence, Kanzas: Geological Soc. America Inc. \& Univ. Kanzas. Part H. Brachiopoda. Revised. Vol.1. Introduction. P.7-188.

Williams A., Lüter C., Cusack M. 2001. The nature of siliceous mosaics forming the first shell of the brachiopod Discinisca // J. Struct. Biol. Vol.134. P.25-34.

Williams A., Rowell A.J. 1965. Brachiopod anatomy // R.C. Moore (ed.). Treatise on Invertebrate Paleontology, Part H, Brachiopoda (Revised). Boulder (Co) -
Lawrence (Ks): Geol. Soc. Am. - Univ. Kansas Press. P.6-57.

Yatsu N. 1902. On the development of Lingula anatina // Journal of the College of Science, Imperial University, Tokyo, Japan. Vol.17. No.4. P.1-112.

Zakrzewski A.-C., Suhb A., Lüter C. 2012. New insights into the larval development of Macandrevia cranium (Müller, 1776) (Brachiopoda: Rhynchonelliformea) // Zool. Anz. Vol.251. P.263-269.

Zhang Z.L., Popov L.E., Holmer L.E., Zhang Z.F. 2018. Earliest ontogeny of early Cambrian acrotretoid brachiopods - first evidence for metamorphosis and its implications // BMC Evol. Biol. Vol.18. No.42. P.115.

Responsible editor E. Temereva 